УДК 159.923 .2

DOI https://doi.org/10.32689/maup.psych.2021.3.1

\title{
Аліна БАХВАЛОВА
}

аспірантка кафедри загальної психології факультету психології, Київський національний університет імені Тараса Шевченка, пр. Глушкова, 2-А, м. Київ, Україна, 03680

ORCID: 0000-0002-2828-2981

\section{Alina BAKHVALOVA}

PhD Student at General Psychology Department of the Faculty of Psychology, Taras Shevchenko National University of Kyiv, 2A Hlushkov Avenue, Kyiv, Ukraine, 03680

ORCID: 0000-0002-2828-2981

\section{ПРОФЕСІЙНА САМООЦІНКА ЖУРНАЛІСТА ЯК ІНТЕГРУЮЧЕ УТВОРЕННЯ ЙОГО ІНДИВІДУАЛЬНОСТІ

JOURNALISTS' PROFESSIONAL SELF-ESTEEM
AS AN INTEGRATING FACTOR OF INDIVIDUALITY

Теорія інтегральної індивідуальності Мерліна В.С. широко використовується дослідниками, оскільки дозволяє системно підійти до вивчення особистості. У даній статті феномен професійної самооиінки та інтегральна індивідуальність поєднуються в рамках дослідження особистості журналіста, а метою статті є обтрунтування професійної самооиінки у якості системотвірного елементу індивідуальності. Для реалізації цієєї мети було досліджено властивості кожного із трьох рівнів інтегральної індивідуальності, а також складові частини професійної самооцінки. Після обчислення інтегрального показника професійної самооцінки був застосований метод часткових корелячій, який дозволяє обрахувати кореляції між індивідуально-психологічними властивостями різних рівнів, виключаючи при иьвому вплив професійної самооцінки на них. Порівняння результатів кореляційного аналізу та методу часткових кореляцій показало, щзо під впливом професійної самооиінки зв'язки між різними рівнями інтегральної індивідуальності змінюються: розпадаються старі та формуються нові. Наприклад, в ергічності з'являється зв 'язок із емоційною стабільністю та спокоєм, але зникає зв'язок із рішучістю, щзо робить ияю властивість основою для розвитку самоконтролю - важливої для журналіста професійної якості. Також вибудовуються зв'язки між конформністю та гуманістичними ичінностями (милосердям та любов'ю), отюее, конформізм стає механізмом соціалізації у професійній групі. Нарешті, цінність соціальної активності втрачає свій зв'язок із низькою моральною нормативністю і перестає бути виявом бунтарського духу, а стає засобом реалізащіі власної життєвої позииії. Така трансформація зв'язків підтверджує, шзо професійна самооцінка є системотвірною міжрівневою структурою, інтегруючим елементом індивідуальності. Новизна роботи полягає в об'єднанні кількох конструктів, щчо раніше вивчалися окремо, в рамках одного дослідження інтегральної індивідуальності журналіста. Результати дослідження мають прикладне значення, адже робота із професійною самооцінкою матиме вплив на особистість журналіста в цүілому.

Ключові слова: психічні властивості, соціально-психологічні властивості, міжрівневі структури.

Merlin's theory of integral individuality is often used by researchers as a methodological basis because it allows approaching the study of personality systematically. The phenomenon of professional self-esteem and integral individuality are combined in this study of the journalist's personality. The article aims to substantiate professional self-esteem as a system-forming element of individuality. To achieve this goal, the properties of the integral individuality three levels', as well as the components of professional self-esteem were studied. After calculating the integrated indicator of professional self-esteem, the method of partial correlations was used. The last allows calculating correlations between individual psychological properties of different levels, excluding the professional self-esteem influence on them. A comparison of classic correlation results and the results of the partial correlations showed that under the influence of professional self-esteem, the relationships between different integral individuality levels change: old ones fall apart and new ones are formed. For example, ergonicity connects with emotional stability and confidence, but its connection with determination falls apart, which makes this property the basis for self-control development and self-control is an important professional quality for a journalist. In addition, the links between conformity (group-orientation) and humanistic values (charity and love) are built, so conformism becomes a mechanism of socialization in a professional group. Finally, the value of social activity loses its connection with low moral standards (low rule-consciousness) and ceases to be a manifestation of a rebellious spirit but becomes a means of realizing one's position in life. The transformations of these relationships confirm that professional self-esteem is a system-forming inter-level structure, an individuality-integrating element. The work novelty is connection of the several previously described constructs in one research of the journalist's integral individuality. The study results have practical application because working with professional self-esteem will impact on journalist's personality.

Key words: mental properties, socio-psychological properties, interlevel structures. 
Постановка проблеми. Дослідження суб'єкта діяльності, відповідаючи запитам із практики та науковим принципам, має бути системним та охоплювати усі рівні детермінації. Саме така системність $є$ основою теорії інтегральної індивідуальності Мерліна В.С., в якій людина постає як єдність організму, психіки та соціально-психологічних властивостей. Даний підхід досить популярний у вітчизняній науці загалом, у тому числі для дослідження представників різних професій. Зазначена системність допомагає вивчити як вроджені властивості нервової системи та темпераменту, так і набуті риси, що можна використати як у цілях профвідбору, так і при створенні рекомендацій щодо саморозвитку та самовдосконалення самих професіоналів.

У ході попереднього вивчення професійної самооцінки журналістів та її детермінант постало запитання щодо того, чи може цей феномен виступити інтегральним утворенням індивідуальності? Складність i, водночас, цікавість даного дослідження полягає у тому, що зазначена у заголовку статті тема $\epsilon$ місцем перетину кількох різних конструктів: інтегральної індивідуальності (дала - II), професійної самооцінки та, власне, особистісних і професійних якостей самих журналістів.

Аналіз останніх досліджень і публікацій. Коротко розглянемо результати дослідження кожного iз зазначених вище напрямків. По-перше, проблема дослідження II та її системотвірного елементу. У ролі останнього можуть виступати: стиль діяльності [2; 5], навчальна активність [1], а також мотивація досягнення, цінності і т.д. [4]. Системотвірним або інтегруючим елементом індивідуальності може виступити такий конструкт, під впливом якого зв'язки між властивостями різних рівнів змінюються: розриваються деякі старі та формуються нові [5; 12]. Теорія інтегральної індивідуальності В.С. Мерліна, в якій три рівні індивідуально-психологічних властивостей (організму, психічних та соціально-психологічних індивідуальних властивостей) об'єднуються у ієрархічну систему за допомогою системотвірних характеристик, використовується у якості методологічної основи для численних досліджень особистості. Щоправда, дослідження індивідуальності професійного журналіста поки що не ввійшло у ці ряди.

Якщо ж говорити про дослідження, в яких предметом виступають індивідуально-психологічні властивості професійних журналістів, то серед них можна виділити кілька основних тематичних груп: 1) дослідження пов'язані із впливом несприятливих обставин на психо- логічне благополуччя журналіста [14], розвитком посттравматичного стресового синдрому [15], психічних розладів [13], копінгових механізмів для боротьби із стресом [17] тощо; 2) дослідження окремих індивідуально-психологічних властивостей, як-от, креативності [7], довіри [10], професійно-важливих якостей [9], цінностей та ролей [16] тощо; 3) створення грунтовних портретів особистості журналіста, близьких до професіограм [3; 6; 18].

Перші дві групи сконцентровані на дослідженні досить вузького предмета, якоїсь конкретної якості або властивості, тоді як третя містить переважно теоретичні, а не емпіричні розробки. Водночас проблема вивчення особистості професіонала, як зазначено вище, потребує системного підходу, що підкреслює як Дзялошинський I.M., так і Корконосенко С.Г. Останній, описуючи журналіста, неодноразово згадує про «індивідуальність автора», його «індивідуальну неповторність» та особливості письма, очевидно, маючи на увазі таку характеристику як індивідуальний стиль діяльності [6].

Отже, системний підхід Мерліна В.С. із інтегруючою ланкою видається надійною методологічною основою для дослідження особистості журналіста. Професійна самооцінка у цьому випадку відіграє роль центрального елементу професійної Я-концепції, а також впливає на рівень загальної успішності [8]. Саме такої точки зору у розумінні професійної самооцінки дотримується Реан А.О., актуалізуючи структуру цього феномена, виділяючи у ньому особистісний та операційно-діяльнісний аспекти, а також самооцінки потенціалу i результату [11]. Однак залишається без відповіді запитання: чи здатна професійна самооцінка виступити системотвірним елементом II?

Мета статті. Обгрунтувати статистично професійну самооцінку у якості інтегруючого утворення у структурі індивідуальності.

Виклад основного матеріалу. Задля пошуку відповіді на основне запитання даного дослідження було обрано такі психодіагностичні методики:

- опитувальник структури темпераменту Русалова (система індивідуальних властивостей організму за Мерліним В.С.);

- 16-факторний опитувальника Р. Кеттела (система індивідуальних психічних властивостей);

- методика COIHТ-2 (діагностика соціального інтелекту) Каліної Н.Ф. та методика діагностики ціннісних орієнтацій особистості Бубнової С.С. (система індивідуальних соціально-психологічних властивостей); 
- методика дослідження професіоналізму журналіста Закірзянової Л.А. (операційнодіяльнісний аспект професійної самооцінки);

- авторська методика дослідження професійно-важливих якостей журналіста (особистісний аспект);

- методика «Мотивація кар'єри», шкала «Кар'єрна інтуїція» (самооцінка потенціалу);

- методика «Інтегральна задоволеність працею» Фетискіна Н.П. (самооцінка результату).

До дослідження було запрошено професійних журналістів із стажем, у середньому, 9 років. Кількість досліджуваних становила 110 людей (83 жінки, 27 чоловіків), у середньому, віком 31 рік.

Обробка результатів передбачала, по-перше, створення єдиного показника професійної самооцінки. Якщо самооцінка результату та потенціалу були представлені двома окремими змінними, то операційнодіяльнісний та особистісний аспект - ні. Для отримання окремих показників за цими аспектами необхідно було використати факторний аналіз, знизивши розмірність даних (восьми шкал для операційно-діяльнісного та трьох - для особистісного аспекта) до одного фактора. На наступному етапі показники чотирьох складових частин професійної самооцінки були об'єднані у один, загальний. Саме цей загальний показник і використовувався в подальших операціях.

Отже, для того, щоб виступити у ролі системотвірного елемента II, професійна самооцінка повинна суттєвим чином впливати на міжрівневі зв'язки у структурі індивідуальності. Для того, щоб дослідити наявність цього впливу, використовувалася наступна стратегія. Частковий кореляційний аналіз показує зв'язки між двома змінними, виключаючи при цьому вплив третьої змінної. Отже, використовуючи часткові кореляції, можна прослідкувати зв'язки у структурі II без впливу зі сторони професійної самооцінки. Натомість класичний кореляційний аналіз відображає зв'язки із врахуванням впливу міжрівневих структур, серед яких присутня і професійна самооцінка (водночас вплив інших, неявних міжрівневих структур на кшталт мотивації або стилю діяльності також не варто відкидати). Порівняння результатів цих двох типів кореляційного аналізу дозволить виявити, які зв'язки утворилися під впливом професійної самооцінки та інших міжрівневих структур. У ході роботи використовувався двосторонній коефіцієнт Пірсона.

Ураховуючи об'єм статті та кількість змінних у дослідженні, неможливо наочно відо- бразити зв'язки між усіма властивостями кожного із трьох рівнів інтегральної індивідуальності. Натомість можна обрати по одній із властивостей на кожному з рівнів та показати усі ії зв'язки із властивостями інших рівнів.

Розпочнемо із системи індивідуальних властивостей організму, де серед усіх структур темпераменту перше місце у Русалова займає предметна ергічність - інтерес до оточуючого середовища, потреба у праці, активність, рухливість. Дана властивість, відповідно до обчислення часткових кореляцій, має статистично значимі зв'язки із психічними властивостями: домінантністю (фактор Е за Кеттелом), експресивністю (F), сміливістю (H), мрійливістю/практичністю (М), екстравертованістю (F2), рішучістю (F3), а також соціально-психологічними властивостями: цінностями пізнання, соціального статусу, відпочинку, соціальної активності та любові (див. рис. 1).

Зазначимо, що структура II $\epsilon$ не стільки ієрархічною, скільки гетерархічною, тобто різні іiі системи знаходяться у координації одна з одною. Отже, маємо змогу прослідкувати зв'язки між рівнем організму та рівнем соціально-психологічних властивостей, що відображено на рис. 1.

Якщо говорити про шкали 16-факторного опитувальника, то негативна кореляція передбачає зв'язок із полюсом мінімальних значень даної шкали, а позитивна - із полюсом максимальних. Ергічність позитивно пов'язана зі фактором Н (сором'язливість/сміливість) і негативно - із фактором М (практичність/ мрійливість), тобто можемо сказати, що вона позитивно корелює зі сміливістю та практичністю. У випадку негативної кореляції із іншими властивостями будуть зазначені обидва полюси фактора за Кеттелом.

Виявлені кореляції не викликають запитань відносно їх логічності, враховуючи, що ергічність відображає інтерес до усіх аспектів та сфер життя. Якщо ж звернутися до класичного кореляційного аналізу, то матриця зв'язків дещо змінить свій вигляд (див. рис. 2).

Для зручності на рис. 1 та 2 зазначений ідентичний набір властивостей аби було простіше орієнтуватися у відмінностях. Отже, 3'явилися або стали статистично значимими зв'язки ергічності з емоційною стабільністю (C), спокоєм/тривожністю $(\mathrm{O})$, рівнем тривоги (F1) та соціальним інтелектом. Натомість розпалися зв'язки із чутливістю/рішучістю (F3) та цінністю відпочинку. Під впливом міжрівневих структур II ергічність як синонім врівноваженості, лабільності нервових процесів корелює зі спокоєм, низькою тривогою, 
витримкою та розумінням соціального контексту; водночас певне протиріччя між ергічністю як рухливістю та цінністю відпочинку знімається. Рішучість (F3), натомість, асоціюється із певною поверхневістю і нечутливістю до деталей, тому зв'язок із нею також розривається. У даному контексті ергічність, фактично, виступає основою розвитку самоконтролю, який є одним 3 ключових факторів у професійній діяльності журналіста.
Останнє твердження тісно пов'язані із припущенням щодо каузальності виявлених зв'язків. Як відомо, рівні II не пов'язані причинно-наслідковими зв'язками безпосередньо, однак опосередковано, через міжрівневі утворення, такий зв'язок можливий [5]. Тому під впливом професійної самооцінки ергічність (як властивість базового рівня) $є$ підгрунтям для розвитку емоційної стійкості та соціального інтелекту, зниження тривожності.

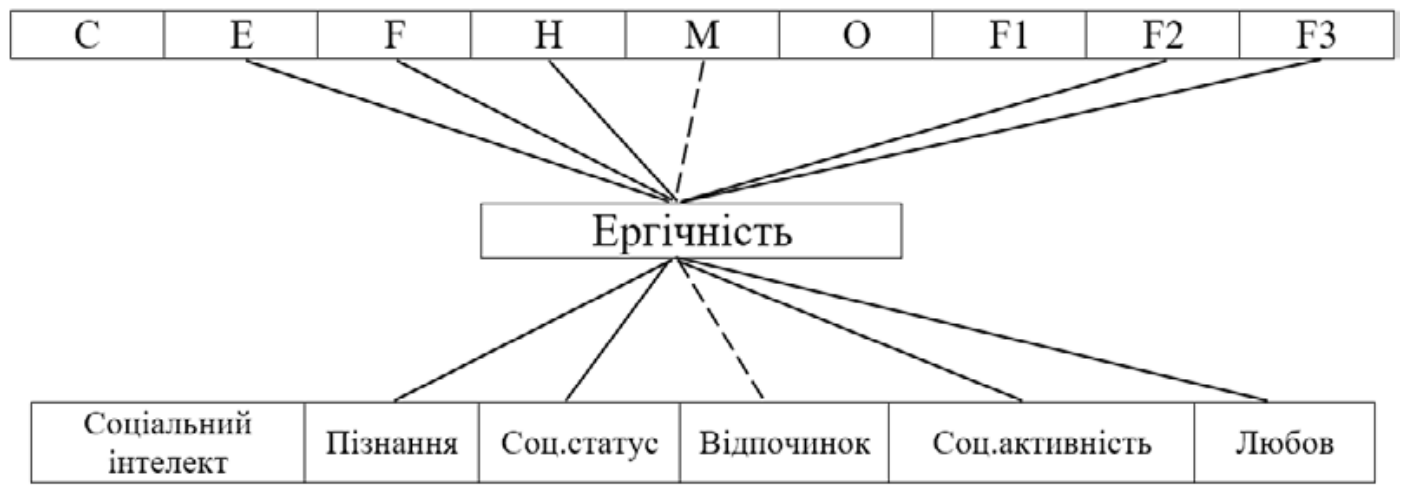

Рис. 1. Зв'язки ергічності із властивостями інших рівнів, виключаючи вплив професійної самооцінки (тут і далі пунктиром позначені негативні кореляції, суцільною лінісю - позитивні; у схемах наводяться лише статистично значимі зв'язки)

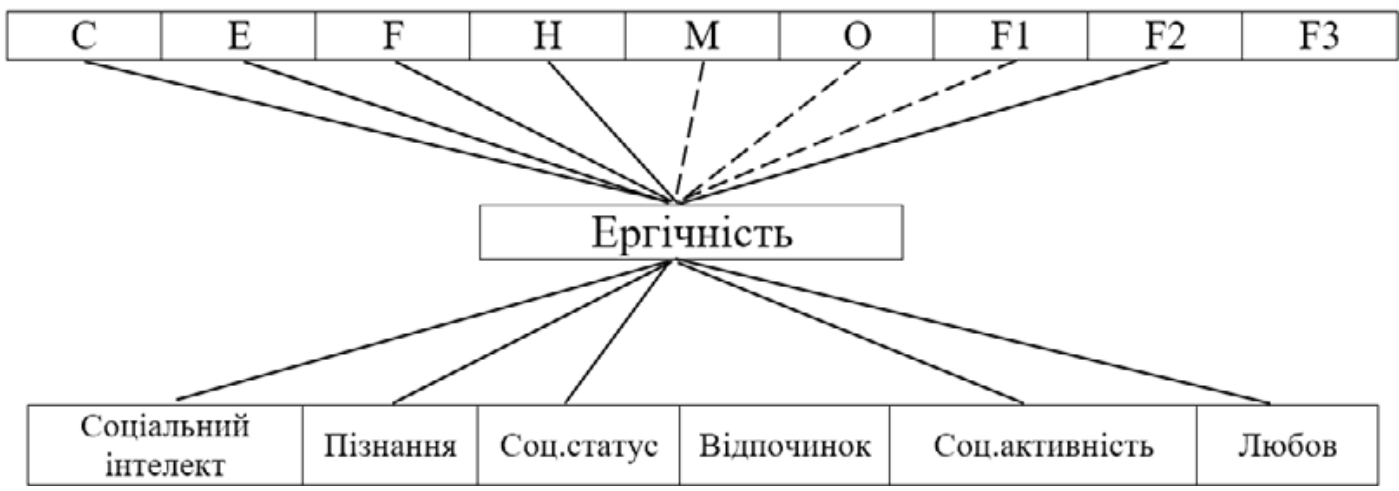

Рис. 2. Зв'язки ергічності із властивостями інших рівнів, враховуючи вплив професійної самооцінки

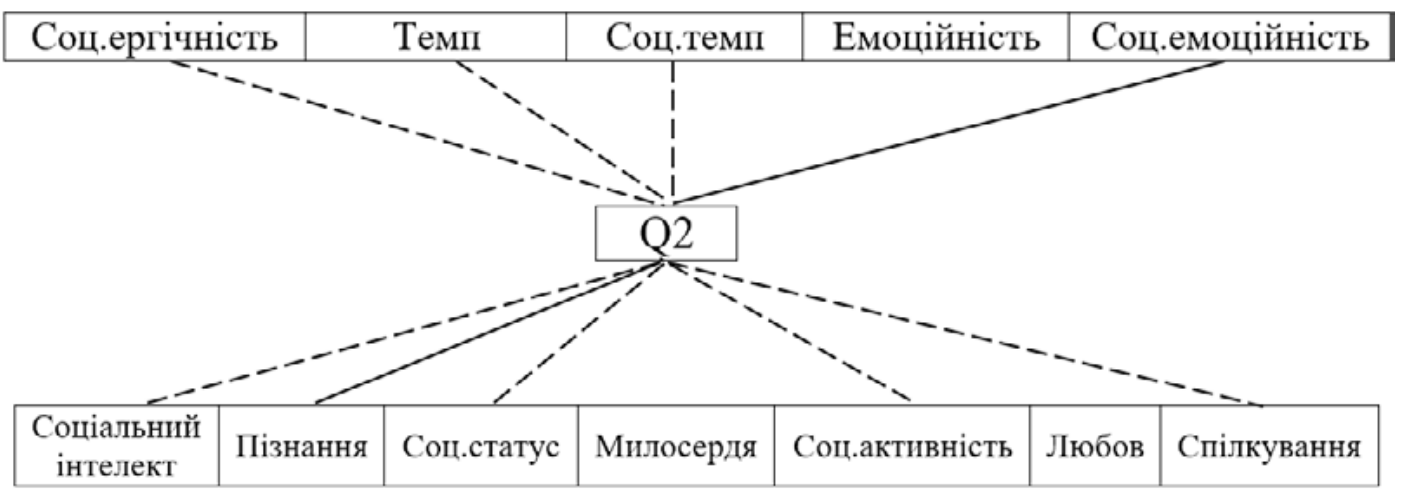

Рис. 3. Зв'язки нонконформізму із властивостями інших рівнів, виключаючи вплив професійної самооцінки 
Із системи індивідуальних психічних властивостей можемо розглянути конформізм/ нонконформізм (фактор Q2 у 16-факторному опитувальнику), адже ця властивість є доволі значимою для журналістів, враховуючи індивідуально-колективний характер їх праці [6]. Отже, зв'язки нонконформізму із властивостями інших рівнів представлені на рис. 3 .

Більшість зв'язків є негативними, адже конформізм (в оригіналі у Кеттела «орієнтація на групу»), важлива для адаптації у професійному середовищі риса, відповідає полюсу мінімальних значень фактора Q2. Отже, вища соціальна ергічність (інтерес до комунікативної сфери), темп (або швидкість нервових процесів) та соціальний темп (швидкість мовлення) пов'язані зі зміщенням до полюсу конформності, орієнтацію на взаємодію з іншими. Те саме стосується соціального інтелекту та цінностей соціального статусу, соціальної активності та спілкування. Натомість соціальна емоційність (концентрація на проблемних ситуаціях у комунікативній сфері) та цінність

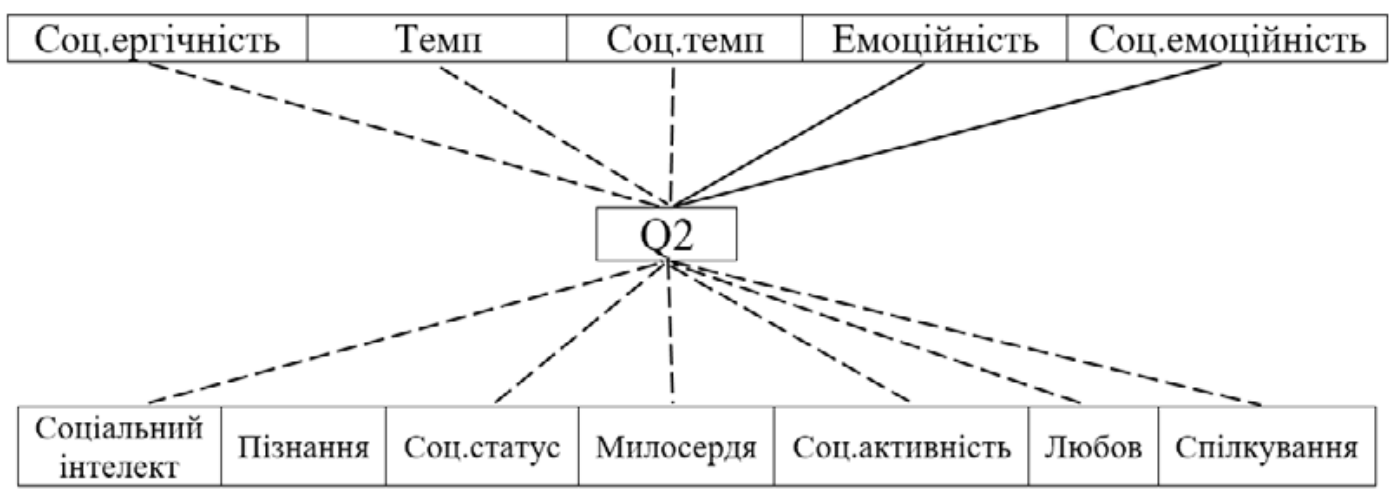

Рис. 4. Зв'язки нонконформізму із властивостями інших рівнів, враховуючи вплив професійної самооцінки

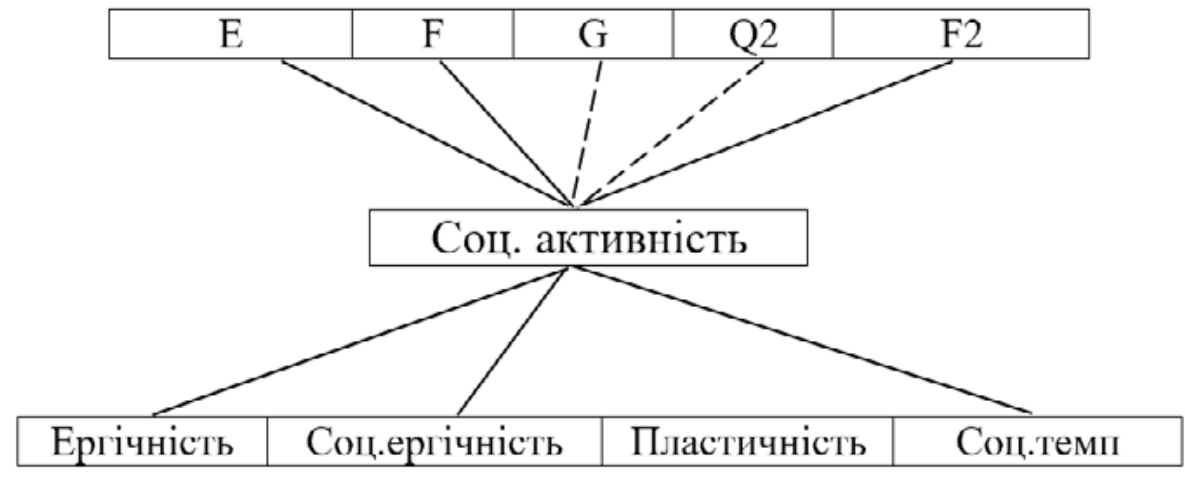

Рис. 5. Зв'язки соціальної активності із властивостями інших рівнів, виключаючи вплив професійної самооцінки

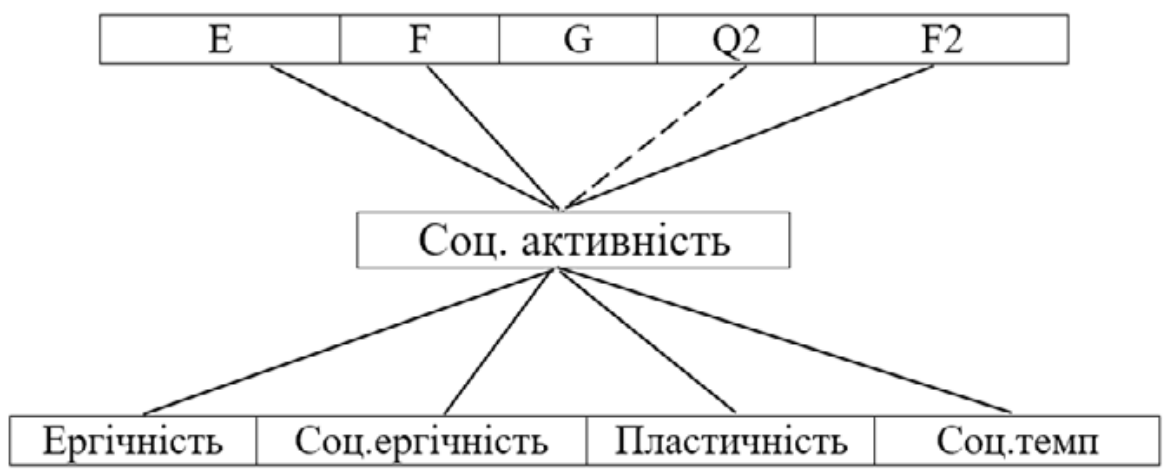

Рис. 6. Зв'язки соціальної активності із властивостями інших рівнів враховуючи вплив професійної самооцінки 
пізнання пов'язані із полюсом нонконформізму, який також можна розуміти як певну відстороненість від інших, самозаглиблення.

Тепер розглянемо ті зміни у зв'язках, які відбулися під впливом міжрівневих структур, у т.ч. професійної самооцінки (див. рис. 4).

Як бачимо, з'явилося декілька нових зв'язків: позитивний - із емоційністю та негативні - із цінностями милосердя та любові. Емоційність відображає певну ригідність та надмірну сензитивність нервової системи, вона близька до соціальної емоційності та пов'язана із застряганням на власних невдачах. Таке зациклювання характерне, як бачимо, для тих журналістів, у кого вищий нонконформізм. Водночас протилежна його сторона - конформізм - пов'язаний із підвищенням значимості милосердя та любові, що цілком обгрунтовано, якщо розуміти конформізм як відчуття приналежності до групи (професійної або спільноти за місцем проживання) та бажання допомогти іншим ії членам.

Цікаво, що розпався один із попередньо наявних зв'язків між нонконформізмом та цінністю пізнання. Очевидно, що під дією професійної самооцінки не лише нонконформні, але і конформні журналісти проявляють однаковий інтерес до опанування нового.

Із соціально-психологічних властивостей третього рівня II оберемо одну із цінностей, яка найкраще відобразить соціальну спрямованість професії журналіста - соціальну активність. Часткові кореляції із властивостями інших рівнів демонструють наступну картину (див. рис. 5).

До вже знайомих нам властивостей домінантності (Е), експресивності (F), конформізму/нонконформізму (Q2) та екстравертованості (F2) додається рівень моральної нормативності (G); із властивостей темпераменту наявні кореляції із ергічність, соціальною ергічністю та соціальним темпом. Незалежність, впертість, життєрадісність, активність, імпульсивність, конформність, екстраверсивність, рухливість та швидкість нервових процесів, інтерес до оточення - все це пов'язано у межах індивідуальності із цінністю соціальної активності. Якщо ж відновити вплив професійної самооцінки на структуру II, то зв'язки зміняться таким чином (див. рис. 6).

Перш за все, зникає доволі неоднозначний зв'язок між низькою моральною нормативністю (G) та соціальною активністю. Очевидно, без впливу професійної самооцінки соціальна активність сприймається як певне бунтарство, імпульсивне та несистемне діяння (участь у різних заходах, мітингах абощо), а от із врахуванням впливу самооцінки даний ефект нівелюється. До речі, таке бунтарство цілком характерне для періоду юнацтва, коли професійна самооцінка (як і професійна ідентичність в цілому) тільки починає формуватися і їі вплив на II є ще досить слабким.

3'являється зв'язок соціальної активності iз пластичністю, тобто гнучкістю та легкістю переключення між різними видами діяльності, що цілком обгрунтовано, оскільки соціальна активність - окремий вид діяльності.

Висновки. Результати даного дослідження показали, що під впливом професійної самооцінки мережа зв'язків між властивостями різних рівнів II змінюється: деякі зв'язки розриваються, а замість них утворюються нові. Це означає, що професійну самооцінку можна вважати повноцінним міжрівневим утворенням II.

До обмежень даного дослідження можна віднести можливий вплив інших міжрівневих утворень на виявлені зв'язки (як у випадку часткових, так і класичних кореляцій). До того ж, були опущені численні подробиці щодо сили кореляцій та рівня їх значимості задля оптимізації об'єму публікації. Подальші дослідження пов'язані із застосуванням виявлених тенденцій на практиці та розробкою рекомендацій по роботі із професійною самооцінкою як системотвірною структурою II.

\section{Література:}

1. Автоматизированный системно-когнитивный анализ и система «Эйдос» в правоохранительной сфере : монография / под ред. проф. Е.В. Луценко. Краснодар : КубГАУ, 2017. 634 с.

2. Вяткин Б.А., Дорфман Л.Я. Теория интегральной индивидуальности В.С. Мерлина: история и современность. Образование и наука. 2017. № 2. С. 145-160.

3. Дзялошинский И.М. Российский журналист в посттоталитарную эпоху. Некоторые особенности личности и профессиональной деятельности. Москва : Восток, 1996. 300 с.

4. Дифференциальная психология: теоретические и прикладные аспекты исследования интегральной индивидуальности : учеб. пособие / под ред. Ахвердова О.А., Волоскова Н.Н., Белых Т.В. СанктПетербург : Речь, 2004. 168 с.

5. Дорфман Л.Я. Методологический анализ теории интегральной индивидуальности В.С. Мерлина. Методология и история психологии. 2008. № 3. С. 106-121.

6. Корконосенко С.Г. Основы творческой деятельности журналиста. Санкт-Петербург : Знание, 2000. $272 \mathrm{c}$. 
7. Мітлош А.В. Індивідуально-психологічні відмінності журналістів різних жанрів професійної діяльності. Актуальні проблеми психології : зб. наук. пращь Інституту психологї ім. Г.С. Костюка НАПН Украӥні. 2012. Т. ХІІ. Психологія творчості. Вип. 15, Ч. ІІ. С. 218-225.

8. Міщенко М.С. Вплив самооцінки на рівень успішності професійної діяльності. Науковий вісник Херсонського державного університету. Серія : Психологічні науки. Херсон : ВД «Гельветика», 2016. Випуск 6. Том 1. С. 78-83.

9. Панасенко Н.М. Професія - журналіст: професійно-важливі якості та психологічні особливості. Актуальні проблеми психологї̈. 2019. Том V, Випуск 19. С. 177-186.

10. Петрик О.В. Довіра як прояв соціального інтелекту у професійній діяльності журналістів. Наукові записки національного університету «Острозька академія». Серія «Психологія». № 5. 2017. C. $120-128$.

11. Реан А.А. Психология личности. Социализация, поведение, общение. Санкт-Петербург : Прайм-Еврознак, 2014. 416 с.

12. Щебетенко А.И. Межуровневые структуры интегральной индивидуальности : монография. Саарбрюкен : Palmarium Academic Publishing, 2012. $420 \mathrm{c}$.

13. Aoki, Y., Malcolm, E., Yamaguchi, S., Thornicroft, G., \& Henderson, C. (2012). Mental illness among journalists: A systematic review. International Journal of Social Psychiatry, 59(4), pp. 377-390.

14. Backholm, K., \& Björkqvist, K. (2010). The effects of exposure to crisis on well-being of journalists: a study of crisis-related factors predicting psychological health in a sample of Finnish journalists. Media, War \& Conflict, 3(2), pp.138-151.

15. Marais, A., \& Stuart, D.A. (2005). The Role of Temperament in the Development of Post-Traumatic Stress Disorder Amongst Journalists. South African Journal of Psychology, 35(1), pp. 89-105.

16. Plaisance, P.L., \& Skewes, E.A. (2003). Personal and Professional Dimensions of News Work: Exploring the Link between Journalists' Values and Roles. Journalism \& Mass Communication Quarterly, 80(4), pp. 833-848.

17. Wang, L., Kang, C., Yin, Z., Su, F. (2019). Psychological endurance, anxiety, and coping style among journalists engaged in emergency events: Evidence from China. Iranian Journal of Public Health, 48 (1), pp. $95-102$.

18. Willnat, L., Weaver, D. H., \& Choi, J. (2013). The Global Journalist in the Twenty-First Century. Journalism Practice, 7(2), pp. 163-183.

\section{References:}

1. Avtomatizirovannyj sistemno-kognitivnyj analiz i sistema «Jejdos» v pravoohranitel'noj sfere : monografija (pod nauchnoj redakciej prof. E.V. Lucenko). [Automated system-cognitive analysis and the "Eidos" system in the law enforcement sphere: monograph, sci. ed. of Prof. Lutsenko]. Krasnodar: KubGAU, 2017. 634 p. [in Russian].

2. Vyatkin B.A., Dorfman L.Ya. Teorija integral'noj individual'nosti V.S. Merlina: istorija i sovremennost'. [Theory of integral individuality by V. S. Merlin: history and nowadays]. Obrazovanie i nauka. 2017. № 2 . P. 145-160. [in Russian].

3. Dzjaloshinskij I.M. Rossijskij zhurnalist v posttotalitarnuju jepohu. Nekotorye osobennosti lichnosti i professional'noj dejatel'nosti. [Russian journalist in the post-totalitarian era. Some features of personality and professional activity]. Moscow: Vostok, 1996. 300 p. [in Russian].

4. Differencial'naja psihologija: teoreticheskie i prikladnye aspekty issledovanija integral'noj individual'nosti. Ucheb. posobie. Pod red. Ahverdova O.A., Voloskova N.N., Belyh T.V. [Differential psychology: theoretical and applied aspects of the study of integral individuality. Textbook, sci. ed. Akhverdova O.A., Voloskova N.N., Belykh T.V.]. Saint-Petersburg: Rech', 2004. 168 p. [in Russian].

5. Dorfman L.Ya. Metodologicheskij analiz teorii integral'noj individual'nosti V.S. Merlina. [Methodological analysis of the theory of integral individuality of V.S. Merlin]. Metodologija i istorija psihologii. 2008. № 3. P. 106-121. [in Russian].

6. Korkonosenko S.G. Osnovy tvorcheskoj dejatel'nosti zhurnalista. [Fundamentals of the creative activity of a journalist]. Saint-Petersburg: Znanie, 2000. 272 p. [in Russian].

7. Mitlosh A. V. Indyvidualno-psykholohichni vidminnosti zhurnalistiv riznykh zhanriv profesiinoi diialnosti. [Individual-psychological differences of journalists of various genres of professional activity]. Aktualni problemy psykholohii: Zb. nauk. prats Instytutu psykholohii im. H.S. Kostiuka NAPN Ukraini. 2012. T. XII. Psykholohiia tvorchosti. Vyp. 15, Ch. II. P. 218-225. [in Ukrainian].

8. Mishchenko M. S. Vplyv samootsinky na riven uspishnosti profesiinoi diialnosti. [The self-effect on the level of professional success]. Naukovyi visnyk Khersonskoho derzhavnoho universytetu. Seriia : Psykholohichni nauky. Kherson : VD «Helvetyka». 2016. Vypusk 6. Tom 1. P. 78-83. [in Ukrainian].

9. Panasenko N.M. Profesiia - zhurnalist: profesiino-vazhlyvi yakosti ta psykholohichni osoblyvosti. [Profession - journalist: professionally important qualities and psychological features]. Aktualni problemy psykholohii. 2019. Tom V, Vypusk 19. P. 177-186. [in Ukrainian].

10. Petryk O. V. Dovira yak proiav sotsialnoho intelektu u profesiinii diialnosti zhurnalistiv. [Trust as a manifestation of social intelligence in the professional activities of journalists]. Naukovi zapysky natsionalnoho universytetu «Ostrozka akademiia», seriia «Psykholohiia», №5, 2017. S.120-128. [in Ukrainian]. 
11. Rean A.A. (2002). Psihologija cheloveka ot rozhdenija do smerti [Psychology of human from birth to death]. Saint-Petersburg: Prajm-Evroznak. 656 p. [in Russian].

12. Shhebetenko A.I. Mezhurovnevye struktury integral'noj individual'nosti. Monografija. [Interlevel structures of integral personality. Monograph]. Saarbrjuken: Palmarium Academic Publishing, 2012. 420 p. [in Russian].

13. Aoki, Y., Malcolm, E., Yamaguchi, S., Thornicroft, G., \& Henderson, C. (2012). Mental illness among journalists: A systematic review. International Journal of Social Psychiatry, 59(4), 377-390.

14. Backholm, K., \& Björkqvist, K. (2010). The effects of exposure to crisis on well-being of journalists: a study of crisis-related factors predicting psychological health in a sample of Finnish journalists. Media, War \& Conflict, 3(2), 138-151.

15. Marais, A., \& Stuart, D.A. (2005). The Role of Temperament in the Development of Post-Traumatic Stress Disorder Amongst Journalists. South African Journal of Psychology, 35(1), 89-105.

16. Plaisance, P.L., \& Skewes, E.A. (2003). Personal and Professional Dimensions of News Work: Exploring the Link between Journalists' Values and Roles. Journalism \& Mass Communication Quarterly, 80(4), 833-848.

17. Wang, L., Kang, C., Yin, Z., Su, F. (2019). Psychological endurance, anxiety, and coping style among journalists engaged in emergency events: Evidence from China. Iranian Journal of Public Health, 48 (1), 95-102.

18. Willnat, L., Weaver, D. H., \& Choi, J. (2013). The Global Journalist in the Twenty-First Century. Journalism Practice, 7(2), 163-183. 